\title{
ПСИХОЛОГІЧНІ МЕХАНІЗМИ ОСОБИСТІСНОГО РЕАГУВАННЯ В СИТУАЦІЇ НЕВИЗНАЧЕНОСТІ
}

\begin{abstract}
Анотація. У статті проаналізовано дослідження феномену невизначеності в сучасній психології та надано їі характеристики. Розглянута сутність та особливості проявів страху особистості. Визначені поняття «копінг-стратегій» та механізмів психологічного захисту особистості в структурі саморегуляції, особливості формування психологічних меж особистості. Проаналізовано основні копінг-механізми, способи подолання труднощів у різних сферах психічної діяльності. Визначено особливості впливу ситуаційного страху на емощійний стан людини в ситуащії невизначеності. Експериментально доведено, що причиною виникнення ситуащійного страху в умовах невизначеності можуть бути порушені особистісні межі.
\end{abstract}

Ключові слова: невизначеність, особистісні межі, страх, ситуативний страх, копінг-механізми, захисні психологічні механізми, механізми прийняття рішень, емощійні прояви.

Stulika Olena, Babkina Anastasiya Mariupol State University

\section{PSYCHOLOGICAL MECHANISMS OF PERSONAL RESPONSE IN A SITUATION OF UNCERTAINTY}

Summary. The article analyzes the study of the phenomenon of uncertainty in modern psychology and provides its characteristics. The essence and features of manifestations of personality fear are considered. The authors claim that uncertainty is mostly due to the lack of information. Uncertainty can arise in various spheres of everyday's life of a person who encounters it in solving certain problems in any sphere of life In the situation of uncertainty, a person has to make a decision, and it is also impossible to understand which of the alternatives will be correct and effective. The situation of uncertainty is always supported by certain emotional states, which can be both negative and positive. Due to the emotional background, the potential problem inherent in any situation becomes a natural obstacle that is realized in human interaction, so any situation of uncertainty adds a certain fear to person's life. The authors presuppose that the result of difficulties in decision-making in a situation of uncertainty may be the emergence of different types of fear depending on the situation. Fear is a state that arises in a situation of uncertainty and poses a threat to human life. The authors consider that the main mechanism for overcoming fear can be personal techniques of control and self-control. Everyone develops certain individual ways to deal with stress, fear and negative emotional states. There are also certain mechanisms of psychological defense that help us process negative experiences and fears. The concepts of "coping strategy" and mechanisms of psychological defense of personality in the structure of self-regulation, features of formation of psychological borders of personality are defined. The main coping mechanisms, ways of overcoming difficulties in various spheres of mental activity are analyzed. The peculiarities of the influence of situational fear on a person's emotional state in a situation of uncertainty are determined. It is experimentally proved that the cause of situational fear under the conditions of uncertainty can be the result of destruction of personal boundaries.

Keywords: uncertainty, personal boundaries, fear, situational fear, coping mechanisms, protective psychological mechanisms, decision-making mechanisms, emotional manifestations.

$\Pi$ остановка проблеми. В сучасних нестабільних умовах життя люди постійно стикаються з низкою проблем орієнтування в навколишній соціальній дійсності. Такі життеві умови призводять до ускладнень при складанні конкретного, структурованого прогнозу свого життя. Невизначеність - це, в першу чергу, відсутність або недостатній об'єм інформації. У той же час невизначеність проявляється у складності формування можливості появи різних станів зовнішнього середовища із-за їх незначної кількості або повної відсутності способів оцінки. У ситуації невизначеності людина повинна прийняти певне рішення, від якого буде залежати результативність виходу 3 ціеї ситуащії, але при цьому часто досить важко зрозуміти, яка з альтернатив буде правильною i результативною. Іноді людині важко зрозуміти перешкоди на шляху вибору конструктивного рішення та ощінити дощільність прийняття того чи іншого рішення в ситуації невизначеності.

Невідомість, невизначеність - це стресова ситуація для людини, тому вона завжди супроводжуеться певними емоційними станами, які можуть бути різними за знаком (позитивні-негативні), за швидкістю розгортання, за якістю прийняття рішення. Але ці емоцийні стани обов'язково впливають на ситуацію та/або вихід із неї. А якщо цей емоційний фрон негативний, то потенційна проблема, що завжди притаманна будь-якій ситуапії невизначеності, стає природною перешкодою, яка реалізуеться у процесі взаємодії, або такою переживається. Саме тому, ситуація невизначеності додає певного страху або певного драйву у життя кожної людини.

Цілком доцільно зазначити, що результатом ускладнень при прийнятті рішень у ситуації невизначеності може бути виникнення різних видів страху в залежності від ситуації. Саме страх $\epsilon$ певним індикатором загрози життедіяльності людини. Але, крім здорового, природного страху, існує страх хворобливий. Цей страх майже постійний і хронічний. Хронічний страх частково проявляеться в таких формах як емоційний шок, жах та інші, він є тривалим і нав'язливим, характеризується повною відсутністю контролю своїх дій. 
Виділення невирішених раніше частин загальної проблеми. Кожна людина протягом життя виробляе певні адаптаційні процеси, індивідуальні способи боротьби зі стресом, страхом та 3 негативними емоційними станами, які можуть бути спрямовані на активну зміну ситуації (копінг-реакції або копінг-стратегії), чи на пом'якшення психологічного дискомфорту у стресовій ситуації.

Почуття страху - це один з компонентів ситуащії невизначеності, коли людина чогось не знає або не може передбачити і ця невизначеність лякає і виводить 3 рівноваги. За страхом може слідувати нерозуміння, паніка, тривога, розчарування і невпевненість в собі, так як страх «оволодіває» людиною, контролює їі дії. Своєчасне визначення особистісного страху і причин його виникнення може позбавити людину від майбутніх його наслідків або послабити їх Якщо копінг-поведінка може використовуватися індивідом свідомо, вибиратися і змінюватися їм в залежності від ситуації, то механізми психологічного захисту неусвідомлювані і в разі їх закріплення стають дезадаптивними. Отже, механіз ми подолання більш пластичні, але вимагають від людини більшої витрати енергії і включення когнітивних, емоційних і поведінкових зусиль. Механізми захисту здатні швидше знизити емоційну напругу і тривогу і працюють за принципом «тут і тепер».

Тому ми вважаємо, що усвідомлення індивідуальних механізмів особистісного реагування в ситуації невизначеності може понизити рівень стресу й сприяти психологічно комфортному переживанню ситуації. Саме тому обрана тема $є$ актуальною.

Розв'язуючи проблему взаємозв'язку психологічних механізмів особистісного реагування в ситуації невизначеності, ми спиралися на дослідження категорії «невизначеності» в психології Є.П. Белінської, В.П. Зінченка, А.С. Шапкіна; аналізу поняття емоцій, емоційного стану та емоційних проявів особистості O.M. Леонтьевим, П.В. Сімоновим, С.Л. Рубінштейном та іншими; поняття страху та його видів Г. Крайгом, У. Джеймсом, С.Ю. Мамонтовим, 3. Фрейдом, Д. Айке та іншими; дослідження копінг-стратегій та механізмів психологічного захисту (К. Гарвер, Р. Лазарус, З. Фрейд, С. Фолкман,); були проаналізовані дослідження меж «Я» у роботах К. Юнга, З. Фрейда, К. Хорні, Ф. Перлз.

Формулювання цілей статті. Мета полягає у дослідженні особливостей усвідомлення взаємозв'язку ситуаційного страху та емоційного реагування людини на цей страх в ситуації невизначеності.

Аналіз останніх досліджень і публікацій. У сучасному суспільстві будь-який вибір або проблемна ситуація включає в себе елемент невизначеності, що передбачає безліч можливих варіантів досягнення результату. О.С. Шапкін вважає, що "невизначеність - це неповне або недостатне уявлення про значення різних параметрів у майбутньому, породжуваних різноманітними причинами, і перш за все, неповнотою або неточністю інформації про умови реалізації рішення, у тому числі пов'язаних з ними витратах і результатах» [2, с. 5].
Для психологічно комфортного існування психічно здорової людини необхідно отримання нею позитивних емоцій, підкріплених поведінкою. Емоційні прояви людини проявляються в певних емоційних реакціях, емоційних процесах, станах, відносинах і стійких рисах особистості. Ситуація невизначеності завжди супроводжуеться різними емоційними станами. О.М. Леонтьев вважав, що «емоції - це наслідок поведінки людини, що задовольняють певні потреби та виступають побудником активності» [6, с. 4]. На думку автора, емоції здатні регулювати і координувати діяльність у відповідності з майбутніми результатами, так само емоції відіграють важливу роль у мотивації.

Г. Плутчик [3] в своїй концепції визначає вісім основних базових емоцій, розділивши їх на 4 пари, які автор пов'язав з певними діями: прийняття чи затвердження, відкидання або огида; відтворення або радість, позбавлення або розчарування; дослідження або очікування, орієнтація чи несподіванка; руйнування або гнів, захист або страх.

Дослідженню поняття страх присвячено значну кількість досліджень. Страх може бути однією 3 причин або джерелом емоційних порушень розвитку особистості [3, с. 60]. Г. Крайг вважає, що "страх це емоція, яку людина намагається уникнути або звести до мінімуму, але водночас страх, проявляючись у м'якій формі, здатний спонукати людину до навчання» $[4$, с. 35]. С.Ю. Мамонтов виділяе наступні групи страхів:

- екзистенційні страхи: страх смерті, страх свободи, страх самотності, страх злиднів;

- страх власної бездарності або нездатності: невідповідність професійним вимогам, страх невдачі, страх бути гірше інших;

- фробії і панічні напади;

- соціальні страхи: такі страхи грунтуються на невпевненості людини в собі, у своїх здібностях, успіхах, на засудженні та образах та поділяються на певні види страхів: страх відкидання, страх втрати, страх прийняти самостійне рішення, страх публічного прояву почуттів, боязнь авторитарних особистостей [1, с. 157].

Страх - це той стан, який виникае та супроводжуе ситуацію невизначеності та являе загрозу продуктивної життедіяльності людини. Страх може виникати, коли людина не може чогось передбачити і ця невизначеність лякає і виводить ї̈ з рівноваги. В різних ситуаціях у різних людей прояв страху різниться як за силою, так і за впливом на поведінку людини. Кожна людина виробляе певні індивідуальні способи боротьби зі стресом, страхом і з різними негативними емоційними станами, тобто особистісні копінг-стратегії [1, с. 156].

В рамках транзактної моделі стресу Р. Лазарус і С. Фолкман зафіксували нове поняття і надали своє розуміння «копінг-стратегій» [6, с. 178]. «Копінг», на їх думку, це метод подолання стресової напруги. «Копінг-стратегії» - це ті чи інші прийоми контролю різних важких ситуацій або станів, які кожна людина відчуває на усвідомлюваному рівні. Подолання важкої життевої ситуащії залежить виключно від особистості суб'єкта і реально-дієвої ситуації [6, с. 178].

Р. Лазарус і С. Фолкман виділяють основні підходи, щодо подолання стресових ситуацій: 
- Диспозиційний підхід розглядае особистісні якості, які $е$ найкращими способами впоратися 3 негативними ситуаціями. Цей підхід розкриває певний зв'язок між особистісними особливостями і результативними і не результативними копінгстратегіями.

- Ситуативний підхід. Р. Лазарус вважав, що саме стресова нестандартна ситуація певним чином впливае і змінюе стиль подолання стресу і страху. Копінг в цій теорії - це не що інше, як поведінкові і когнітивні зусилля, які людина прикладає для того, щоб послабити стресовий вплив [6, с. 180].

Копінг-стратегії дозволяють вільно діяти і адаптуватися до умов, що змінюються. Завдяки особистісним паттернам людина формуе своє ставлення до різних проблем, які виникають в життедіяльності. Але, якщо копінг-стратегію людина обирае свідомо з метою активного реагування на стресову ситуацію, то психологічний захист розглядаеться як пасивна копінг-поведінка, а захисні механізми - як інтрапсихичні форми подолання стресу, призначені для зниження емоційної напруги раніше, ніж перерветься ситуація (Лазарус, Фолкман). На думку З. Фрейда «...захисні механізми - це такі собі форми несвідомої психічної активності, спрямовані на усунення психологічного дискомфорту, неприемних переживань, що виникають в результаті загрози самоповазі чи цілісності особистості...» [9, с. 140]. Дані механізми спотворюють різні тривожні аспекти реальності, витісняють їх зі свідомості, при цьому дозволяючи особистості зберегти найбільш важливі для iï позитивної ідентичності уявлення про своє «Я» і про навколишню дійсність. Основний функщіонал даних механізмів полягае в послабленні тривоги, фрустрації і занепокоення, викликаних протиріччям між імпульсами несвідомого і певними вимогами зовнішнього середовища.

Захист нашого «Я» проявляеться не тільки через захисні механізми, а й за допомогою усвідомлюваних особистісних меж [5, с. 256]. Ф. Перлз визначае межі як наявність «Я» і «не-Я», тобто це місце, де закінчуеться особистісне «Я» і починаеться хтось або щось інше [8, с. 55]. Межі рухливі, мінливі та містять у собі певні причини того, що відбуваеться з «Я». Кожна людина по-різному визначае свої межі, по-різному їх відчувае, тому дослідники (З. Фрейд, Ф. Перлз) визначають, що сприйняття своїх меж - це неусвідомлене почуття, яке проявляеться в переживанні обмеженості від зовнішнього середовища [8, с. 59].

Гіпотезою нашого дослідження виступае те, що не сформованість або не усвідомлення власних особистісних меж є причиною первинного виникнення особистісного страху в ситуації невизначеності.

Виклад основного матеріалу дослідження. 3 метою перевірки гіпотези було проведено експериментальне дослідження, яке складалося з констатувального, корекційного та контрольного етапів. У констатувальному етапі взяли участь 71 респондент, віком від 20 до 30 років представники різних професійних напрямів: вихователі закладів дошкільної освіти та курсанти-слухачі Донецького юридичного інституту MBC України (м. Маріуполь). Батарею методик склали «Іерархічна структура актуальних страхів особистості» (Ю. Щербатих, Є. Івлева), яка до- зволяе визначити показник особистісних страхів, а також наявність / відсутність фобій; «Оцінка особистісної тривожності» (Х. Спилбергер), спрямована на виявлення рівня ситуативної та особистісної тривожності; «Оцінка поведінки у важкій життевій ситуації (Р. Лазарус, С. Фолкман) 3 метою визначення копінг-механізмів, способів подолання труднощів та копінг-стратегій учасників; "Суверенність психологічного простору» (С.К. Нартова-Бочавер) для виявлення суверенності психологічного простору і встановлення сформованості особистісних меж; «Механізми психологічного захисту» (П. Келлерман, Конте), для виявлення механізмів психологічного захисту, які допомагають зберегти стабільність самооцінки, уявлень про себе і про світ.

За результатами методики «Іерархічна структура актуальних страхів особистості» (Ю. Щербатих, Є. Івлева) було визначено, що у $20 \%$ респондентів домінуе страх хвороби близьких. Даний страх респонденти позначали цифрою 10, що визначається як високий показник страху; у 7\% досліджуваних визначено наявність страху до змін в особистісному житті; у 7\% - страх війни. Методика дозволяе виявити інтегральний показник особистісного страху, за яким було визначено 5 учасників, у яких діагностовано завищений показник страху та 1 респондент 3 низькім показником страху, яких було включено до групи корекції.

За результатами методики «Оцінка особистісної тривожності» (Х. Спилбергер) було визначено, що у $3 \%$ діагностовано завищену ситуативну тривожність і у $6 \%$ особистісну тривожність. Тож, на нашу думку, даний рівень тривожності може бути причиною певного особистісного страху.

За результатами копінг-тесту «Оцінка поведінки у важкій життевій ситуації» (Р. Лазарус, C. Фолкман) було отримано наступні результати: копінг конфронтація спостерігається у 50\% досліджуваних; копінг дистанціювання спостерігаеться у 58\%; копінг самоконтроль виявляеться у $30 \%$ респондентів; копінг пошук соціальної підтримки відзначаеться у 47\% досліджуваних; копінг прийняття відповідальності спостерігаеться у 43\% респондентів; копінг втеча-уникнення спостерігаеться у 51\% досліджуваних; копінг планування-вирішення проблеми відзначаеться у $25 \%$ учасників; копінг позитивна переоцінка обирають $35 \%$ респондентів.

За методикою "Суверенність психологічного простору» (С.К. Нартова-Бочавер) було визначено учасників, у яких показник сформованості особистісних меж нижчий від визначеного критерію. Позначивши шкалу поняттям «депривованість», маючи на увазі обмеженість різних умов, які необхідні для певного розвитку, та проаналізувавши результати, було встановлено наявність депривованості психологічного простору особистості у $6 \%$ учасників, не сформованість суверенності фізичного тіла у 5\% учасників, суверенності світу речей у $3 \%$ учасників, звичок у $4 \%$ і суверенності цінностей у $2 \%$ учасників. Також ми встановили, що у респондентів, не зважаючи на їх депривованість суверенності психологічного простору, сформовано суверенність території та суверенність соціальних зв'язків.

За результатами методики «Механізми психологічного захисту» (П. Келлерман, Конте) було 
констатовано, що найбільш виражені захисні механізми серед респондентів - це витіснення (37\%) і раціоналізація (37\%). Менш вираженим захисним механізмом є гіпєркомпенсація (10\%). Автори методики вважають, що найбільш конструктивними психологічними механізмами є компенсація та раціоналізація, та також деструктивними механізмами вважаються проекція та витіснення.

Отже, проаналізувавши результати констатувального етапу дослідження, ми зробили наступні висновки:

1. У досліджуваних діагностовано завищений інтегральний показник особистісного страху, також домінуючи страхи респондентів - це страх хвороби близьких, страх змін в особистісному житті і страх війни.

2. У респондентів встановлено вираженість ступеня особистісної та ситуативної тривожності.

3. Більшість досліджуваних (50\%) обирають такі копінги, як втеча-уникнення та дистанщіювання.

4. В досліджуваних (16\%) визначено низький рівень сорормованості психологічного простору.

5. Учасники найчастіше використовують такі захисні механізми як витіснення і раціоналізація $(37 \%)$.

На другому етапі нашого дослідження, враховуючи результати діагностичного етапу, була розроблена та впроваджена корекційна програма, спрямована на усвідомлення особистісного страху і його подолання; формування адекватної самооцінки та зниження рівня тривожності; корекцію суверенності психологічного простору особистості та розвиток адаптивних способів прийняття рішень в ситуації невизначеності. В корекційній програмі взяли участь 16 досліджуваних, в яких за результатами констатувального етапу спостерігався високий показник інтенсивності особистісних страхів, підвищення рівню особистісної тривожності, деструктивні способи подолання труднощів, часткові порушення сфрормованості суверенності психологічного простору. Корекційна програма впроваджувалася у вересні-листопаді 2020 року.

Тема першого тренінгового заняття: «Профілактика особистісного страху і його подолання». Мета: зниження емоційної напруги і тривожного стану, а також розуміння і подолання власного страху.

Структура заняття:

1. Встановлення групових правил.

2. Налагодження контакту: Вправа «Ім'я фракти».

3. Робота з подоланням особистісного страху: Вправа «Намалюй свій страх».

4. Рефрлексія: Вправа «Побажання у колі».

Тема другого тренінгового заняття: «Корекція самооцінки та подолання негативних емоцій, викликаних страхом». Мета: подолання негативних переживань та емоцій, які викликає страх, створення адекватної самооцінки за допомогою усвідомлення своєї індивідуальності.

Структура заняття:

1. Згуртування групи: вправа «Я сьогодні як хто?».

2. Подолання негативних емоцій та підвищення самооцінки: вправа "Чарівний напис», вправа «Я-персонаж», вправа «Ось який я».

3. Фінальна редрлексія.
Тема третього тренінгового заняття: «Формування суверенності психологічного простору особистості». Мета: формування особистісних меж, зняття напруги і тривожного стану, корекція цілісного «Я-образу, а також фрормування адекватної самооцінки особистості.

Структура заняття:

1. Привітання, підвищення настрою: вправа «Предмети».

2. Робота з корекцією «Я-образу»: вправа «Маска», вправа «Три портрета».

3. Фінальна редрексія.

Тема четвертого тренінгового заняття: «Розвиток адаптивних способів прийняття рішення». Мета: сорормувати способи долаючої поведінки та навички аналізу проблем і прийняття рішень.

Структура заняття:

1. Об єднати групу для подальшої роботи: вправа "М'яч-знайомства».

2. Робота зі способами прийняття рішень: вправа «Проблема та їі рішення», вправа «Реалізація бажань».

3. Рефрлексія з рекомендаціями для учасників.

Після корекційної програми було проведено контрольне тестування учасників задля порівняння результатів до та після проведення тренінгових занять.

Була повторно використана методика «Іерархічна структура актуальних страхів особистості» (Ю. Щербатих і Є. Івлєва). Було виявлено, що показник особистісного страху у учасників значно змінився. Нормою особистісного страху вважається 82,6\%. За даною методикою середньою нормою показника страху у чоловіків $\epsilon$ $77.9 \pm 4.7$ балів, у жінок $-104,0 \pm 2.5$ балів. Показник особистісного страху може бути як нижче ціеї норми, так і вище. За результатами констатуемо зміну рівню особистісного страху, у кожного учасника (відсоток інтегрального показника особистісного страху відповідає нормативному значенню). 3 цього можна зробити висновок, що на цей момент страх не є загрозою і значною проблемою для особистості кожного учасника (див. табл. 1).

Завдяки повторному тестуванню за методикою «Оцінка особистісної тривожності» (Х. Спилбергер), було констатовано, що усі учасники змогли впоратися зі своєю особистісною тривожністю. Низка тривожність вважається до 30\%, помірна тривожність до 44\%. За допомогою корекційної роботи у всіх учасників рівень особистісної тривожності змінився на помірний (див. табл. 1).

Результати за методикою «Оцінка поведінки у важкій життевій ситуації» (Р. Лазарус, С. Фолкман) демонструють, що після проведення корекційної програми учасникам вдалося змінити або усвідомити способи поведінки в конфліктній ситуації, тобто вони свідомо обирають конструктивні способи впораючої поведінки. На етапі констатувального дослідження учасники обирали такі копінг-стратегії як втеча-уникнення, пошук соціальної підтримки та дистанціювання, то на етапі контрольного дослідження визначено, що учасники обирають самоконтроль, планування рішень та прийняття відповідальності, що свідчить про сформовану особистісну навичку аналізу проблем і прийняття конструктивних рішень в ситуації конфрлікту та в ситуаціях невизначеності. 
Таблиця 1

Порівняння результатів за методиками: «Іерархічна структура актуальних страхів особистості» (Ю. Щербатих і С. Івлева), "Оцінка особистісної тривожності» (Х. Спилбергер), “Суверенність психологічного простору» (С.К. Нартова-Бочавер).

\begin{tabular}{|c|c|c|c|c|c|c|}
\hline \multirow{2}{*}{$\begin{array}{c}\text { Номер } \\
\text { учасника }\end{array}$} & \multicolumn{2}{|c|}{$\begin{array}{c}\text { Методика «ерарх. структ. } \\
\text { акт. страхів» }\end{array}$} & $\begin{array}{c}\text { Методика «Оцінка особист. } \\
\text { тривож.» }\end{array}$ & \multicolumn{2}{|c|}{$\begin{array}{c}\text { Методика «Сувер. псих. } \\
\text { простору» }\end{array}$} \\
\cline { 2 - 7 } & $\begin{array}{c}\text { Докор. } \\
\text { роботи }\end{array}$ & $\begin{array}{c}\text { Після кор. } \\
\text { роботи }\end{array}$ & $\begin{array}{c}\text { Докор. } \\
\text { роботи }\end{array}$ & $\begin{array}{c}\text { Після кор. } \\
\text { роботи }\end{array}$ & $\begin{array}{c}\text { Докор. } \\
\text { роботи }\end{array}$ & $\begin{array}{c}\text { Після кор. } \\
\text { роботи }\end{array}$ \\
\hline 1 & $96 \%$ & $79 \%$ & $41 \%$ & $36 \%$ & $47 \%$ & $73 \%$ \\
\hline 2 & $86 \%$ & $80 \%$ & $42 \%$ & $35 \%$ & $48 \%$ & $72 \%$ \\
\hline 3 & $111 \%$ & $85 \%$ & $50 \%$ & $34 \%$ & $56 \%$ & $73 \%$ \\
\hline 4 & $108 \%$ & $80 \%$ & $40 \%$ & $36 \%$ & $61 \%$ & $75 \%$ \\
\hline 5 & $56 \%$ & $79 \%$ & $46 \%$ & $39 \%$ & $48 \%$ & $75 \%$ \\
\hline 6 & $95 \%$ & $81 \%$ & $45 \%$ & $37 \%$ & $61 \%$ & $76 \%$ \\
\hline 7 & $101 \%$ & $80 \%$ & $45 \%$ & $40 \%$ & $60 \%$ & $76 \%$ \\
\hline 8 & $98 \%$ & $81 \%$ & $51 \%$ & $42 \%$ & $38 \%$ & $73 \%$ \\
\hline 9 & $99 \%$ & $78 \%$ & $50 \%$ & $43 \%$ & $40 \%$ & $74 \%$ \\
\hline 10 & $90 \%$ & $79 \%$ & $45 \%$ & $39 \%$ & $41 \%$ & $75 \%$ \\
\hline 11 & $105 \%$ & $82 \%$ & $47 \%$ & $40 \%$ & $47 \%$ & $75 \%$ \\
\hline 12 & $89 \%$ & $84 \%$ & $45 \%$ & $40 \%$ & $45 \%$ & $72 \%$ \\
\hline 13 & $90 \%$ & $79 \%$ & $52 \%$ & $43 \%$ & $50 \%$ & $70 \%$ \\
\hline 14 & $100 \%$ & $80 \%$ & $50 \%$ & $41 \%$ & $46 \%$ & $73 \%$ \\
\hline 15 & $101 \%$ & $83 \%$ & $48 \%$ & $40 \%$ & $40 \%$ & $71 \%$ \\
\hline
\end{tabular}

Результати методики «Суверенність психологічного простору» (С.К. Нартова-Бочавер): показник суверенності психологічного простору після корекційної роботи підвищився по всіх шкалах. Шкали вимірювання психологічного простору особистості: суверенність фрізичного тіла, суверенність території, суверенність світу речей, суверенність звичок, суверенність соціальних зв'язків, та суверенність цінностей. За результатами було зроблено висновок про те, що робота 3 фрормування психологічних меж одного показника означає формування меж іншого показника. В таблиці представлені результати сорормованості суверенності психологічного простору (див. табл. 1).

Методика «Механізми психологічного захисту» (П. Келлерман, Конте). За результатами повторного тестування ми визначили, що у досліджуваних спостерігаються зміни певних захисних механізмів. Після проведення контрольного етапу експериментального дослідження було встановлено, що захисний механізм раціоналізація у учасників не змінився, що свідчить про те, що досліджувані обирають конструктивні дії для подолання негативної ситуації. Також встановили зміни деструктивних механізмів, які позначалися у учасників раніше. Психологічні механізми витіснення і проекція, після проведеної корекційної роботи змінилися на заміщення і компенсацію. 3 цього можна зробити висновок, що учасники провели рефлексивно-конструктивну роботу над собою.
Висновки 3 даного дослідження. В peзультаті експериментального дослідження було виявлено, що страх як неконтрольована емоція первинно виникає в ситуації невизначеності, і цей страх може бути причиною появи тривоги, дискомфорту і напруги в даній ситуащії, що ще більше може посилити інтенсивність особистісного страху. Негативні емоційні стани впливають на прийняття рішення у ситуації невизначеності. Через емоційний фон потенційна проблема, притаманна будь-якій ситуації, стає природною перешкодою, яка реалізуеться у взаємодії людини. Різні емоційні стани, які проявляються в ситуації невизначеності, можуть стати перешкодою для утримання особистісних меж. Коли в ситуації невизначеності виникає тільки страх і не спостерігаеться прийняття конструктивного рішення, це свідчить про не впевнену сформованість психологічних меж, які визначаються через розуміння власного «Я» як цілісного і окремого від інших.

Для того, щоб в ситуащії невизначеності не виникав первинно особистісний страх, а навпаки, людина обирала конструктивні захисні психологічні механізми і копінг-стратегії, необхідно сdрормувати позитивну Я-концепщію та усвідомити свій цілісний Я-образ. Це дасть можливість розуміння особистісних кордонів, їх утримання і тим самим свободу в діях і виборі - тобто адекватне реагування в ситуації невизначеності. А якості перспективи подальшого дослідження вбачаємо можливість дослідити взаємозв'язок страху та особистісних механізмів реагування на нього на етапі старіння. 


\section{Список літератури:}

1. Агавелян В. С., Васильева Т. Н., Габдреева Г. Ш., Прохоров О. О. Теоретичні та прикладні аспекти психології станів. Психологія станів : хрестоматія. Москва : Наукова думка; Санкт-Петербург : Речь, 2004.157 с.

2. Аліша Б. С. Психіка і подолання невизначеності. Психологія: журнал Вищої школи еконоліки / ред.: Т. М. Ушакова. Москва : Державний університет. Вища школа економіки, 2009. № 3. С. 3-26.

3. Ганзен В. А. Систематизація психічних станів. Психологія станів : хрестоматія / скл. Т. Н. Васильева, Г. Ш. Габдреева, А. О. Прохоров / під. ред. А. О. Прохорова. Москва : Наукова думка; Санкт-Петербург : Речь, 2004. С. 60-64.

4. Горохова Л. В. Страх як екзистенціал буття сучасної людини. Вісник Житолирського державного універсиmemy. 2010. Вип. 53. С. 33-36.

5. Конопкін О. А. Психологічні механізми регуляції діяльності. Москва: вид-во Наука, 1980. 256 с.

6. Лазарус Р. Теория стресса и психофизиологические исследования. Эмоциональный стресс. Москва, 1990. C. $178-208$

7. Леонтьев О. М. Потреби, мотиви і емоції: конспект лекцій. Москва : вид-во МГУ, 1971. 40 с.

8. Марциновская Т. Д. Психологические границы: история и современное состояние. Мир психологии. 2008. № 3. C. 55-62.

9. Фрейд А. Психологія «Я» і захисні механізми. Москва : Педагогіка-Прес, 1993. 140 с.

\section{References:}

1. Agavelyan V. S., Vasilieva T. N., Gabdreeva G. S., Prokhorov O. O. (2004) Theoretical and applied aspects of state psychology. Psychology of states: a textbook. Moscow: Scientific Opinion; St. Petersburg: Rech, $157 \mathrm{p}$

2. Alicia B. S. (2009) Psyche and overcoming uncertainty. Psychology: Journal of the Higher School of Economics / ed.: T. M. Ushakova. Moscow: State University. Higher School of Economics, no. 3, pp. 3-26.

3. Hansen V. A. (2004) Systematization of mental states. Psychology of states: a textbook / comp. T. N. Vasilieva, G. Sh. Gabdreeva, A. O. Prokhorov / under. ed. A. O. Prokhorov. Moscow: Scientific Opinion; Saint-Petersburg: Rech, pp. 60-64.

4. Gorokhova L. V. (2010) Fear as an existential being of modern man. Bulletin of Zhytomyr State University, vol. 53, pp. 33-36.

5. Konopkin O. A. (1980) Psychological mechanisms of activity regulation. Moscow: Nauka Publishing House, $256 \mathrm{p}$.

6. Lazarus R. (1990) Theory of stress and psychophysiological research. Emotional stress. Wetness, pp. 178-208.

7. Leontiev O. M. (1971) Needs, motives and emotions: lecture notes. Moscow: Moscow State University, $40 \mathrm{p}$

8. Martsinovskaya T. D. (2008) Psychological boundaries: history and current state. World of Psychology, no. 3, pp. 55-62.

9. Freud A. (1993) Psychology of «I» and protective mechanisms. Moscow: Pedagogy-Press, $140 \mathrm{p}$. 